\title{
SOCIALIZATION OF MASS TRANSPORTATION IN MADRASAH IBTIDAIYAH NURUL HIDAYAH KECAMATAN PANCORAN, JAKARTA SELATAN
}

\author{
Muhammad Isradi, Acep Hidayat, and Soh Aly \\ Universitas Mercu Buana Jakarta, Indonesia \\ Union of The Youth Federation of Cambodia, Cambodia.
}

\begin{abstract}
Traffic congestion in the Jakarta Capital City has become a public secret. Various solutions have been put forward and have even begun to be implemented by the Jakarta city government, such as the construction of Non-Toll Flyover (JLNT), the construction of Mass Rapid Transit (MRT), Light Rapid Transportation (LRT) and continuous improvement on other mass transportation services such as Busway and KRL. As the number two megapolitan in the world, Jakarta has never been free from traffic jams. Like Tokyo, Bangkok and New York City, traffic hours in Jakarta are classified as very acute. An extraordinary breakthrough is needed, to overcome this problem. Actually the problem of traffic congestion in Jakarta is not new. Based on statistical data, the growth of motor vehicles in Jakarta annually reaches $9.5 \%$. This figure is not comparable to the growth of the length of the highway, which is only around $0.01 \%$ per year. There have been various ways taken by the government to overcome congestion in the capital city. Against this background, it is necessary to conduct socialization early on about mass transportation knowledge, especially for young children at elementary school level, so it is hoped our children already have provisions information and knowledge about the importance of using public / mass transportation modes in our country..
\end{abstract}

Keyword : Mass Transportation, Congestion, Knowledge

\section{BACKGROUND}

Congestion is characterized, theoretically, by unstable flows, slow vehicle travel speeds, and long vehicle queues, which usually occur at concentrations of socio-economic activity or at traffic intersections in urban centers. Severe traffic congestion as happened in Jakarta can be viewed from 2 (two) sides, namely the supply (supply) and demand (demand) side. The unavailability of alternative modes results in the entire burden of circulation on road infrastructure, while the low availability of public transport causes very high dependence on private vehicles. The existence of public transportation in Jabodetabek has not been able to meet the needs of the movement of people in Jabodetabek. Data shows that 7 million people make daily traffic movements in Jabodetabek, of which 3.08 million use private vehicles and the rest use public transportation modes. As an illustration, the busway that has been relied upon by the DKI Jakarta Government so far has only been able to transport 210,000 people / day or around $6 \%$ of the total people who carry out the movement. (4)

Conversely, mass transportation is not comfortable, forcing people to survive by finding alternatives themselves. Now, a rational choice falls on motorbikes. In addition to being affordable, operating costs and effectiveness tend to be more efficient. No wonder there are currently around nine million motorcycles in Jakarta. Besides that, it is easy to have private vehicles as well as triggering urban congestion, especially ownership of motorized vehicles or two-wheeled vehicles.

In the traffic system, the actual physical movement of transport takes place in space and time, assuming that people and goods move together with the means of transport along the physical network (1).For this reason, the Department of Public Works should also encourage its partners, especially the Ministry of Transportation, to complete the National Transportation System (SISTRANAS) and other transportation policy derivatives. Without the National Transportation System and the expected integrated transportation policy, the development of the integrated transportation sector in the Greater Jakarta Area will be difficult to achieve, and thus the problem of severe traffic congestion in this region will never be completely resolved. The handling of transportation in Jakarta as the concept presented by the Minister of Transportation in front of the Vice President of the Republic of Indonesia on May 30, 2008 was only part of a permanent, comprehensive and long-term solution to overcome traffic congestion in Jakarta and its surroundings. For the Medium and Long Term, the megapolitan concept that was proposed by Governor Sutiyoso deserves to be reviewed more seriously. In this megapolitan frame, the problem of congestion can also be related to the problem of flooding / inundation, because all of them are related. Dep. MPW needs to consider the impact of toll road construction on increasing the intensity of flooding in the 
Greater Jakarta area, and vice versa, the impact of flooding / inundation on increasing congestion and decreasing road quality (3).

The use of private vehicles is more efficient, it needs to be programmed carpool matching. This is necessary to match the origin of almost the same travel destination that is done in almost the same time of departure / return by a number of people (5). Management of the car / bus shuttle school students is actually based on carpool matching thinking. So far the school has manually matched the origin of the trip and has relatively succeeded in controlling the needs of vehicle circulation and parking around school entry / exit hours. Found that one of the reasons parents subscribe to school shuttle facilities is because they think this service is safer when compared to existing public transportation (5)

\section{PURPOSE}

In this community service activity, the socialization provided aims to:

1. Provide information and knowledge about the benefits of using public transportation (mass transportation).

2. Provide information about the development of mass transportation facilities and infrastructure that are being built in the Capital City of Jakarta.

3. Provide any impact information due to the use of private vehicles

4. Provide an understanding of the age that is allowed to drive a vehicle

The benefits to the community in this activity:

Providing information, knowledge and early understanding of the importance of the use of public transportation / mass transportation and any impacts caused by the use of private vehicles as well as information about the development of mass transportation that is developing now.

\section{METHOD APPLICATION}

The main activity is to provide socialization and increase knowledge to students about the use of public / mass transportation in our country. The method used is to give an explanation to grade 6 students by presenting several teaching aids such as:

a) Pictures of facilities and models of mass transportation,

b) Video of mass transit systems in modern cities,

c) Videos on how school children in developed countries use mass transit,

d) Video about information on the construction of mass transit infrastructure in our country

The method used is to give an explanation to grade 4 students by presenting several teaching aids such as:

In its implementation, this activity is carried out in several stages, namely:

- Coordination with school authorities to arrange the time and space for implementation

- Determine the socialization participants who will get material from this activity

- Provide sufficient knowledge to students / facilitators as resource persons for this socialization activity

- Prepare work materials and tools such as display banner images, laptops, LCD projectors

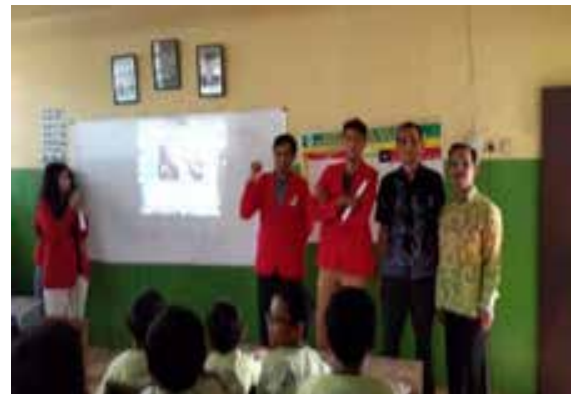

Fig.1 Video playback to students

\section{RESULT}

From the socialization activities, students are collected in the classroom then we present material about the dissemination of knowledge about good and right traffic. Displayed pictures and video shows about various types and benefits of mass transit. 

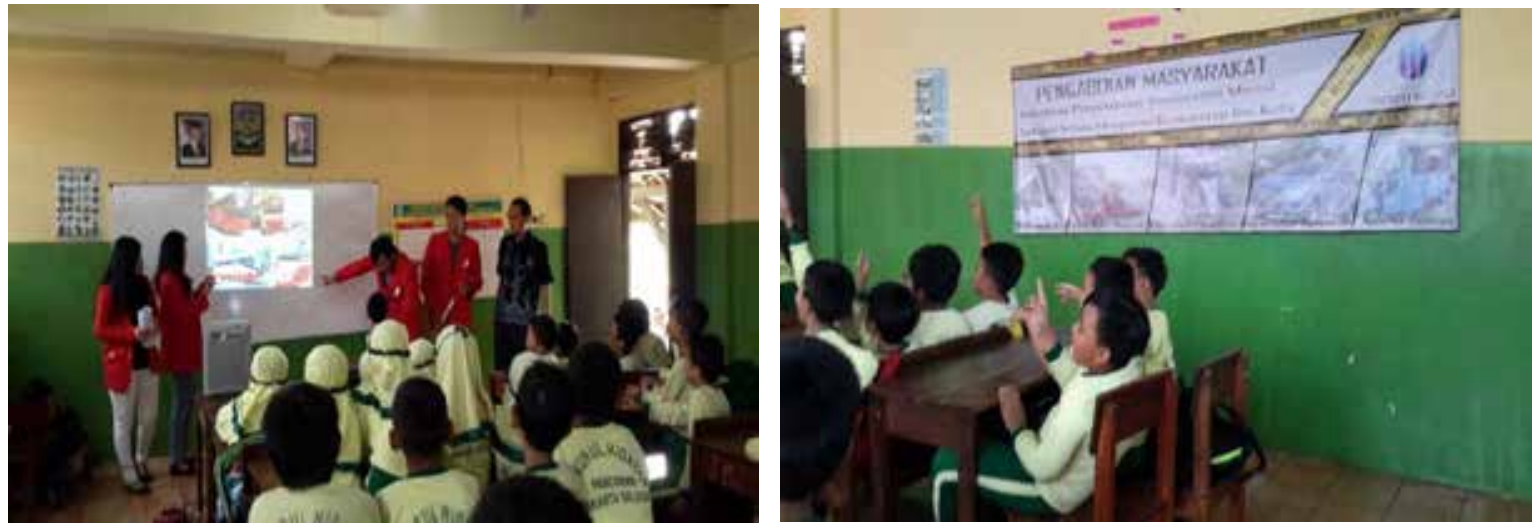

Fig.2 Student socialization and interactive

Initially students have very poor patterns of thinking and understanding of the information on the types of mass transportation available in our country and abroad. Also an understanding of the importance of the use of mass transit. This activity was carried out for 90 minutes, attended by 1 lecturer and 6 students of the Civil Engineering study program at Mercubuana University Jakarta and 40 fourth grade students at MI Nulul Hidayah Pancoran, Jakarta.

In this activity also provided discussion and evaluation of the results of the socialization, where at the end of the activity students are given questions about the material that has been submitted as evaluation material for the implementation team.
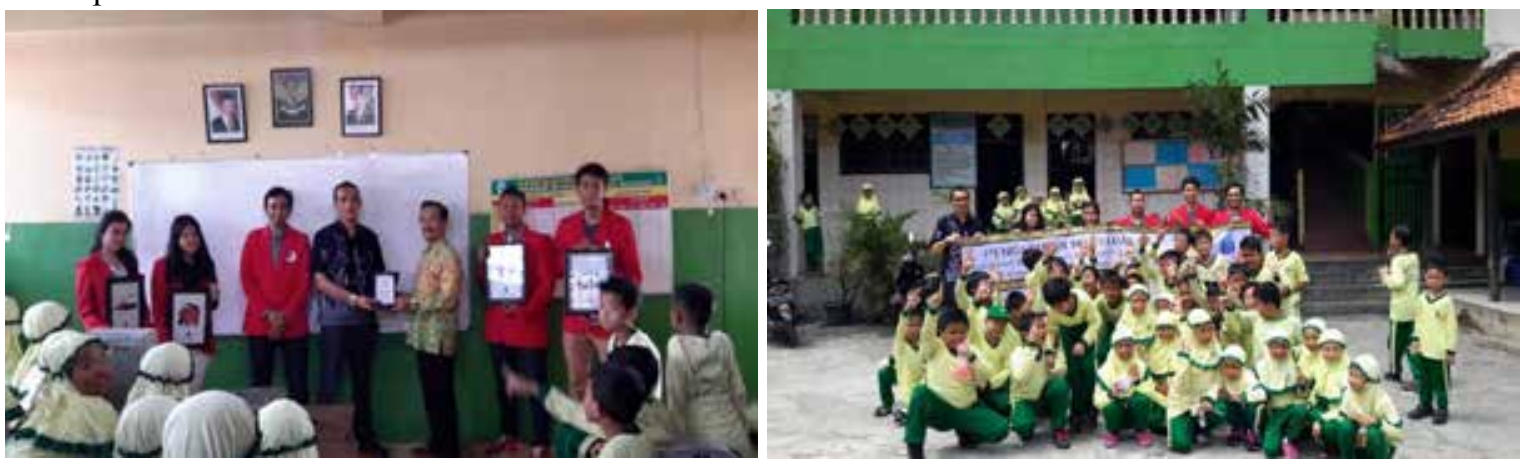

Fig.3 Discussion and evaluation of activities

\section{CONCLUSION}

This socialization activity provides and enhances students' understanding of the importance of using mass transportation or public transportation for MI Nurul Hidayah Pancoran Students, Jakarta. What impact will happen if many people use private vehicles and do not want to switch to using public transportation. He conveyed that the impact of congestion in the capital city of Jakarta is getting worse and any losses due to the congestion.

Student activeness in this activity in the form of discussion and question and answer is expected to add insight and knowledge to students on the importance of using public transportation and is expected to be applied in daily activities

\section{REFERENSI}

1. Khisty, C. Jotin \& B. Kent Lall. (2005). "Dasar-Dasar Rekayasa Transportasi”. Erlangga. Jakarta

2. Miro, Fidel. (2012), "Pengantar Sistem Transportasi”. Erlangga, Jakarta

3. http://www.kompasiana.com/afandri_adya/solusi-kemacetan-jakarta_juni, 2015

4. http://www.pu.go.id/isustrategis/view/24 nop 2016

5. Putranto, L.S, (2013), Rekayasa Lalulintas, Indeks, Jakarta

6. Tamin, Ofyar Z. (2000), Perencanaan dan Pemodelan Transportasi, Edisi Kedua, Penerbit ITB, Bandung. 